\title{
EXPERIMENTAL INVESTIGATION OF MOMENT REDISTRIBUTION IN RC CONTINUOUS BEAMS WITH T-CROSS SECTION CONSIDERING CENTRAL LOADED SUPPORT
}

\author{
Hesham M. A. Diab \\ Associate Professor, Civil Engineering Department, Faculty of Engineering, \\ Assiut University, Egypt \\ Tarek Abdelaleem Abdelfattah Khaled \\ Assistant Lecturer, Civil Engineering Department, Faculty of Engineering, \\ Assiut University, Egypt \\ Mohamed M. M. Rashwan \\ Professor, Civil Engineering Department, Faculty of Engineering, \\ Assiut University, Egypt
}

\begin{abstract}
This paper investigates experimentally the relation between tensile reinforcement of sagging and hogging region on the performance of the reinforced concrete continuous T-beams and their effect on the moment redistribution. Four two-span RC continuous beams were manufactured and tested up to failure, three of them were designed with a loaded central concrete column. This research provides an insightful and comprehensive description of the carrying capacity, deformation, ductility index, and moment redistribution of the continuous beam with the different steel reinforcement ratio at critical zones. The results show that the load-carrying capacity of continuous beams depends mainly on the longitudinal reinforcement at sagging region rather than that of the hogging region. The sagging reinforcement improves the ductility and the serviceability of the continuous beams at the allowable deflection and the permissible crack width. The moment redistribution ratio depends on the ratio between the sagging reinforcement and the hogging reinforcement areas, especially after the yielding loads. At the hogging and sagging regions with equal reinforcement areas, the moment redistribution values were reduced in comparison to the other tested beams.
\end{abstract}

Keywords: continuous beams, moment redistribution, ductility, sagging and hogging region, serviceability, crack width 
Cite this Article: Hesham M. A. Diab, Tarek Abdelaleem Abdelfattah Khaled and Mohamed M. M. Rashwan, Experimental Investigation of Moment Redistribution in RC Continuous Beams with T-Cross Section Considering Central Loaded Support, International Journal of Civil Engineering and Technology, 11(7), 2020, pp. 114-130. https://iaeme.com/Home/issue/IJCIET?Volume=11\&Issue=7

\section{INTRODUCTION}

In previous years, the majority of the experimental research was carried out on the simple beams, whether to study the behaviour under vertical loads, the influence of the concrete compressive strength, the form of longitudinal and transverse reinforcement or to study the strength of beams due to defects in the design, implementation or environmental conditions by using steel plates or FRP material [1-7]. Few researches have studied the behaviour of the RC continuous beams [8 -11], despite the importance of the RC continuous beams in the vital structures such as concrete bridges, factories, ...etc., and it is most likely to act as main components. Over the last few years, there has been a focus on studies of the flexural performance of the strengthened RC continuous beams under vertical loads [12-17], the effect of the strengthening method on the moment redistribution ratio, and the efficiency by using the external prestressing system [18-23]. It was noted that the majority of the constructed continuous beams are supported on columns, unlike the previous researches, which had steel plates as supports. So, Farahbod et al. [17] worked on an experimental investigation of moment redistribution of continuous beams in 6 two-span RC frames strengthened with CFRP sheets. The effect of high strength concrete on the ductility and deformation of the RC continuous beams is important. Carmo et al. [9] examined the influence of the tensile reinforcement ratio and the transverse reinforcement ratio in continuous high strength concrete beams on the rotation capacity of the plastic hinge and they revealed that the moment redistribution was not only influenced by the plastic rotation capacity of the critical sections, but also by the relative stiffness of those critical sections initiated by concrete cracking. Due to the nonlinear structural behaviour of reinforced concrete structures, linear elastic analysis can lead to an inaccurate evaluation of the performance and, therefore, it can become crucial to use more progressive methods to reach appropriately precise analysis [8]. Niklas et al. [8] presented an experimental result for twelve two-span rectangular reinforced concrete beams and investigated the effect of the longitudinal tensile reinforcement ratio at the intermediate support, the transverse reinforcement ratio and the concrete strength. The test result showed that the evolution of the moment redistribution at the ultimate limit state was significantly dependent on the arrangement of longitudinal reinforcement [8]. Previous researches did not concern on the effect of main steel reinforcement at each critical section on the efficiency and behaviour of RC continuous beams in yield loads or service loads. Whereas, the load-carrying capacity of the RC continuous beam does not depend on the reinforcement of the one critical section. moreover, these studies focused on the effect of reinforcement ratios on the moment redistribution between the critical sections .There is, however, still a certain lack of consensus regarding the value of the redistribution coefficients [24-26], because of the clear difference in these values. Therefore, this study aims at investigating the behaviour of RC continuous Tbeams when varying the area of the longitudinal reinforcement at the hogging or the sagging region and with a central loaded column in order to get the minimum area of the longitudinal reinforcement which maintains the load-carrying capacity and the serviceability of the tested beams, the effect of this variation on the moment redistribution ratio and the effect of central loaded columns on the performance of the statically indeterminate beams. 


\section{TEST PROGRAM}

The test specimens consisted of four RC two-span continuous beams as given in Table1. The first one was a RC T-cross section continuous beam (C1) with $4300 \mathrm{~mm}$ length and, the Tcross section dimensions were $200 * 230 \mathrm{~mm}$ and $400 * 70 \mathrm{~mm}$ for the web and flange respectively. Beam "C1" was reinforced with four high tensile steel bars of 10 and $12 \mathrm{~mm}$ diameter on the flange of the beam and four high tensile steel bars of $16 \mathrm{~mm}$ diameter on the positive moment region (Figure 1). The other three specimens were two-span RC frames (C2, $\mathrm{C} 3$, and C4) as shown in Figure 2. The lengths of the beams and height of the columns were $4300 \mathrm{~mm}$ and $700 \mathrm{~mm}$, respectively, and the cross-section dimensions of the columns were $200 * 200 \mathrm{~mm}$. The dimensions of the beams were the same as beam C1. The transverse reinforcement in the continuous beams was designed to prevent shear failure. Closed stirrups with $8 \mathrm{~mm}$ diameter spaced at $100 \mathrm{~mm}$ were provided for shear. All columns were reinforced with four $12 \mathrm{~mm}$ bars as a longitudinal reinforcement and $8 \mathrm{~mm}$ transverse reinforcement at intervals of $100 \mathrm{~mm}$. By prestressing a $25 \mathrm{~mm}$ deformed bar, the central columns were loaded by about $120 \mathrm{kN}$ as a constant load before loading the beams. Beam dimensions and reinforcement, as well as the loading and support arrangement for beams C1, C2, C3 and C4, are illustrated in Figure 2.
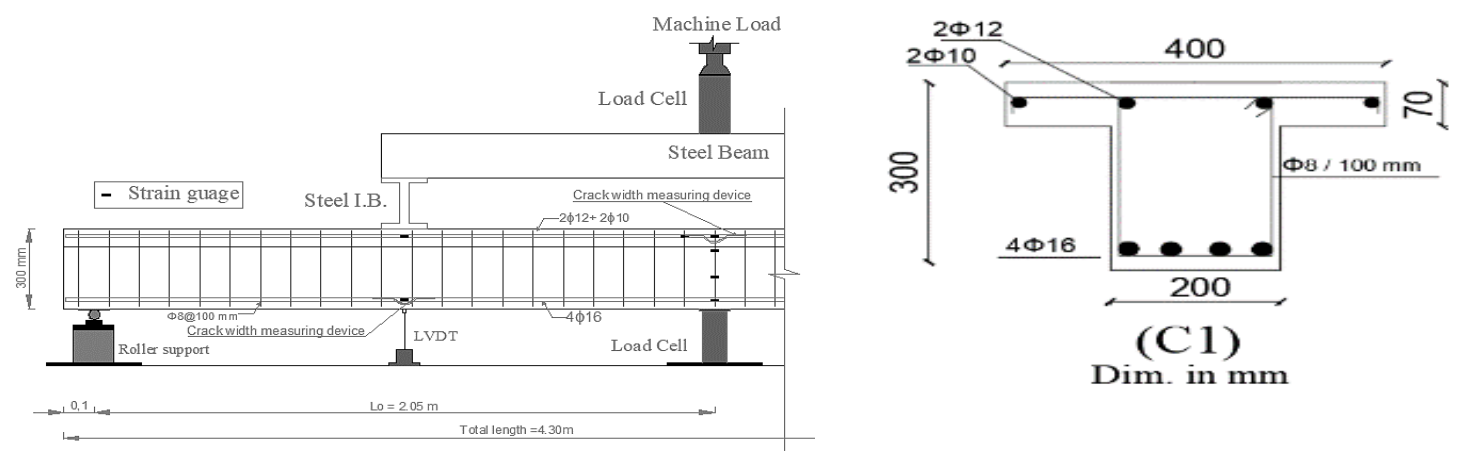

Figure 1 Details of reinforcement, typical cross-section and test set up instrumentations and for C1.

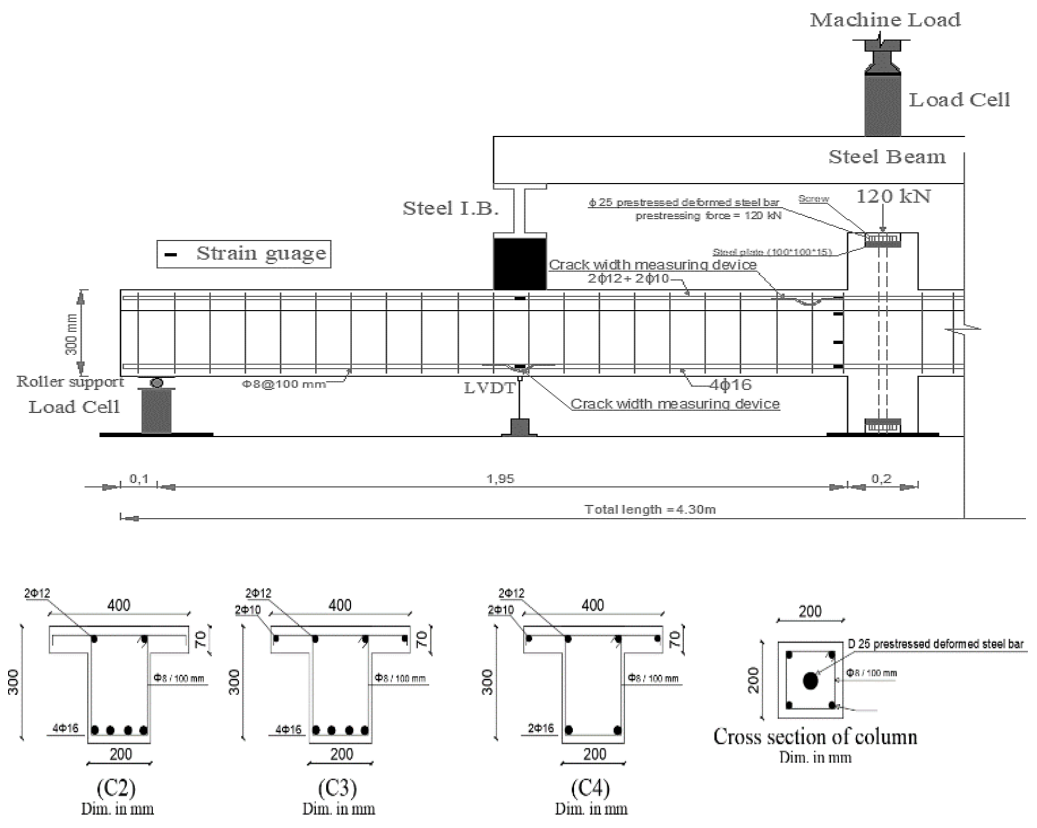

Figure 2 Details of reinforcement, typical cross-sections and test set up and instrumentations for $(\mathrm{C} 2, \mathrm{C} 3$ and $\mathrm{C} 4)$ 
Experimental Investigation of Moment Redistribution in RC Continuous Beams with T-Cross Section Considering Central Loaded Support

Table 1 Compressive strength for the tested beams and reinforcement arrangement

\begin{tabular}{|c|c|c|c|c|c|c|c|}
\hline \multirow[b]{2}{*}{ Beam } & \multirow[b]{2}{*}{$\begin{array}{c}\boldsymbol{f}_{c u} \\
(\boldsymbol{M P a})\end{array}$} & \multirow[b]{2}{*}{$\begin{array}{c}\text { Length } \\
\text { m }\end{array}$} & \multirow[b]{2}{*}{$\begin{array}{c}\text { Steel shear } \\
\text { stirrups }\end{array}$} & \multicolumn{2}{|c|}{ Bottom RFT. } & \multicolumn{2}{|c|}{ Top RFT. } \\
\hline & & & & Reinforcement & $\begin{array}{c}\text { Ratio } \\
\%\end{array}$ & Reinforcement & $\begin{array}{c}\text { Ratio } \\
\%\end{array}$ \\
\hline C1 & 33 & \multirow{4}{*}{4.30} & \multirow{4}{*}{$\begin{array}{c}\text { Ф8@100 } \\
\text { mm }\end{array}$} & $4 \phi 16$ & 1.54 & $2 \phi 12+2 \phi 10$ & 0.74 \\
\hline $\mathrm{C} 2$ & 35 & & & $4 \phi 16$ & 1.54 & $2 \phi 12$ & 0.43 \\
\hline $\mathrm{C3}$ & 34 & & & $4 \phi 16$ & 1.54 & $2 \phi 12+2 \phi 10$ & 0.74 \\
\hline $\mathrm{C4}$ & 36 & & & $2 \phi 16$ & 0.77 & $2 \phi 12+2 \phi 10$ & 0.74 \\
\hline
\end{tabular}

\section{MATERIAL PROPERTIES}

All beams were made of typical normal strength concrete, the concrete had a mix proportion of 1:1.70:2.66 (Cement: Sand: Coarse aggregate) by weight of cement, and coarse aggregates of a maximum nominal size of $10 \mathrm{~mm}$. The water-cement ratio was 0.45 and the designed 28day cube compressive strength of concrete was $30 \mathrm{MPa}$. The compressive strength $f_{c u}$ of the concrete obtained for each beam from compression tests carried out on three $150 \mathrm{~mm}$ cubes on test day is given in Table 1 .

High tensile steel used for the longitudinal reinforcement and mild steel for shear reinforcement (stirrups), the mechanical properties of the reinforcing bars used in this study are given in Table 2.

Table 2 Mechanical Properties of the Reinforcement Bars:

\begin{tabular}{|c|c|c|c|c|c|c|c|}
\hline $\begin{array}{c}\text { Bar } \\
\text { size }\end{array}$ & $\begin{array}{c}\text { Bar } \\
\text { diameter } \\
(\mathbf{m m})\end{array}$ & $\begin{array}{c}\text { Bar } \\
\text { Area } \\
\left(\mathbf{m m}^{\mathbf{2}}\right)\end{array}$ & $\begin{array}{c}\text { Modulus } \\
\text { of } \\
\text { elasticity } \\
(\mathbf{G P a})\end{array}$ & $\begin{array}{c}\text { Yield } \\
\text { Strength } \\
(\mathbf{M P a})\end{array}$ & $\begin{array}{c}\text { Yield } \\
\text { strain } \\
(\boldsymbol{\mu} \boldsymbol{\Sigma})\end{array}$ & $\begin{array}{c}\text { Tensile } \\
\text { Strength } \\
(\mathbf{M P a})\end{array}$ & $\begin{array}{c}\text { Ultimate } \\
\text { strain } \\
(\boldsymbol{\mu} \boldsymbol{\Sigma})\end{array}$ \\
\hline $\mathbf{8}$ & 7.6 & 45.36 & 200 & 360 & 2800 & 482 & 72820 \\
\hline $\mathbf{1 0}$ & 10 & 78.5 & 196 & 509 & 3010 & 665.80 & 65000 \\
\hline $\mathbf{1 2}$ & 12 & 113 & 210 & 522 & 3280 & 640.60 & 58543 \\
\hline $\mathbf{1 6}$ & 15.95 & 199.81 & 203 & 542 & 3680 & 637.81 & 45180 \\
\hline
\end{tabular}

\section{INSTRUMENTATION AND TEST SETUP}

For beam C1 (without central loaded column), one load cell was used at central support to measure the central support reaction during the test. While for the other beams, the central supports were loaded columns, and two load cells were used at the end supports. Also, for all beams, LVDTs were used under load points in the middle of each span to measure the deflections as shown in Figures 1 and 2. Additionally, crack width gauges were installed in the middle of each span to record the crack width at the sagging region. For the hogging region, the Crack width gauge was installed at the centre of the beam $\mathrm{C} 1$, while there were two Crack width gauges were installed next to the column for beams (C2, C3, and C4). Regarding electrical strain gauges for beam $\mathrm{C} 1$, they consisted of seven electrical strain gauges for longitudinal reinforcement, for the hogging region (two strain gauges for 10 and 12 $\mathrm{mm}$ bars) at the critical section and one strain gauge for $12 \mathrm{~mm}$ bar at a $100 \mathrm{~mm}$ from the centre of the beam. For the sagging region, one strain gauge was fixed at the main steel reinforcement and another one was fixed at the compression steel at the critical section of every span. Additionally, three concrete electrical strain gauges were used at the hogging critical section to observe the neutral axis depth at every stage of loading for all tested beams. The beams (C2, C3, and C4) had one strain gauge at the main steel reinforcement for each 
mid-span section and there were two electrical strain gauges for the main longitudinal reinforcement at hogging region next to the central column.

\section{EXPERIMENTAL RESULTS AND DISCUSSION}

A 5,000-kN hydraulic machine was used to apply concentrated load on a stiff steel beam that in turn transmitted the load to the midpoint of each span. The load applied on each span was then evenly transferred to the beam by the associated steel beam. Loading was applied at a rate of $15 \mathrm{kN} / \mathrm{min}$. Readings of all instrumentations were acquired and stored using a data logger (TDS 150) system monitored by a computer. The obtained experimental results are presented and discussed subsequently in terms of the observed mode of failure, crack width, load-deflection response, ductility analysis, load-carrying capacity, flexural rigidity, energy absorption, strain in reinforcement, load-carrying and moment redistribution. The measured initial crack, service, yield and ultimate loads of test specimens are shown in Table 3.

Table 3 Experimental results at cracking, service yield and ultimate loads of test specimens.

\begin{tabular}{|c|c|c|c|c|c|c|c|c|c|c|c|c|}
\hline \multirow[b]{2}{*}{$\begin{array}{c}\text { Beam } \\
\text { Specime } \\
\text { n }\end{array}$} & \multicolumn{2}{|c|}{$P_{c r}(\mathrm{kN})$} & \multicolumn{4}{|c|}{$P_{\text {service }}(\mathbf{k N})$} & \multicolumn{4}{|c|}{$P_{y}(\mathbf{k N})$} & \multirow[b]{2}{*}{$\begin{array}{c}\boldsymbol{P}_{\boldsymbol{u}} \\
(\mathbf{k N})\end{array}$} & \multirow[b]{2}{*}{$\begin{array}{l}\lambda \\
\%\end{array}$} \\
\hline & $\begin{array}{l}\text { Hoggin } \\
\text { g } \\
\text { region }\end{array}$ & $\begin{array}{c}\text { Saggin } \\
\mathbf{g} \\
\text { region }\end{array}$ & $\begin{array}{c}\text { At } \\
l / 480\end{array}$ & $\begin{array}{l}\lambda \\
\%\end{array}$ & $\begin{array}{l}\text { At } \\
l / \mathbf{1 8 0}\end{array}$ & $\begin{array}{l}\lambda \\
\%\end{array}$ & $\begin{array}{l}\text { Hoggin } \\
\mathbf{g} \\
\text { region }\end{array}$ & $\begin{array}{l}\lambda \\
\%\end{array}$ & $\begin{array}{l}\text { Saggin } \\
\mathbf{g} \\
\text { region }\end{array}$ & $\lambda \%$ & & \\
\hline $\mathrm{C} 1$ & 82 & 72 & 188 & 29 & $\begin{array}{c}437.7 \\
5\end{array}$ & 12 & 393.75 & 6 & $397.5^{*}$ & $\begin{array}{c}18 . \\
1\end{array}$ & 437.5 & 12 \\
\hline $\mathrm{C} 2$ & 88 & 76.5 & 260 & 1 & 467.5 & 6 & 295 & 30 & $426.5^{*}$ & $\begin{array}{c}12 . \\
1\end{array}$ & 467.5 & 6 \\
\hline $\mathrm{C} 3$ & 85.25 & 80.75 & 263 & - & $\begin{array}{c}497.7 \\
5\end{array}$ & - & 419.5 & - & $\begin{array}{c}485.25 \\
*\end{array}$ & - & $\begin{array}{c}497.7 \\
5\end{array}$ & - \\
\hline $\mathrm{C} 4$ & 92.75 & 84 & 215 & 18 & 330 & 34 & 316.5 & 25 & 332.75 & $\begin{array}{c}31 . \\
5\end{array}$ & $\begin{array}{c}362.2 \\
5\end{array}$ & 27 \\
\hline
\end{tabular}

$\lambda \%$ : percentage of the shortage of the load carrying capacity compared to beam C3.

*After ultimate load.

\subsection{General behaviour, Cracking Pattern and Failure Mode}

The cracking pattern for all beams is shown in Figure 3. In general, the first crack for all tested beams was observed at the mid-span region, this crack occurred at approximately $16.50 \%, 16.40 \%, 16.20 \%$ and $23 \%$ of the ultimate load for beam C1, C2, C3 and C4 respectively. The second crack started to form in the hogging region at a percentage of $18.70 \%, 18.80 \%, 17.10 \%$ and $25.40 \%$ of the ultimate load, respectively. It is clear that the first cracks at any region depend heavily on the compressive concrete strength. Increasing the load led to more cracks value at the sagging and hogging regions. Until the steel yielding, the distance between the cracks at the positive moment region was roughly equal to the distance between transverse reinforcement.

The traditional ductile flexural failure occurred for all beams as a result of yielding of the longitudinal tensile steel reinforcement, followed by concrete crushing at the central support and the mid-span sections. Strain measurements of tensile steel in middle support and midspan regions of the tested beams uncovered that, as expected, a plastic hinge was formed firstly upon the yielding of the upper tensile steel in the hogging region. After the yield of the hogging tensile steel, expansion of the flexural cracks, the rotation of the beam in this region, and redistribution of moments occurred from the central support toward the positive moment region of the beam. Once yielding of the bottom reinforcement, the concrete at the compression regions reached to its ultimate crushing strain. The modes of failure for all tested beams are shown in Figures 4, 5, 6, and 7. For all beams, the cracks spread up to the ultimate 
load and then the crack width increased until failure load except for the beam $\mathrm{C} 4$, where the failure load was equal to the ultimate load. The cracking patterns for the tested beams at failure are shown in Figure 3. In these figures, the following is observed:

$\mathrm{C} 1$. The flexural crack at the mid-span region began to spread toward the flange at load 77 $\mathrm{kN}$, while the flexural shear crack started to form at load $160 \mathrm{kN}$. At the hogging region, $\mid$ the flange was completely cracked at load $190 \mathrm{kN}$ (43.5\% of its ultimate load). The shear crack which started close to the end support at load $290 \mathrm{kN}$, however the shear crack at the central support started at load $320 \mathrm{kN}$. The negative cracks spread to $400 \mathrm{~mm}$ from the centre of the middle support and toward the point load.

C2. The first mid-span crack started to spread at load $111.0 \mathrm{kN}$, but the crack at the central support continued up to $220 \mathrm{~mm}$ from the top at load $133 \mathrm{kN}$ (28.5\% of its ultimate load). At a distance of $370 \mathrm{~mm}$ from the end support, the shear crack began to start at load $360 \mathrm{kN}$ and the shear cracks became closer to the support at load $380 \mathrm{kN}$. The beam (C2) had flexural reinforcement at the middle support less than the other beams, so it had fewer and wider cracks at the hogging region compared to the others.

C3. Uniform crack distribution in both sagging and hogging regions was observed for this beam. The spacing between cracks was less than the others. The flexural crack extended at load $137 \mathrm{kN}$. At load $160 \mathrm{kN}$ (32.0\% of its ultimate load), the crack at the middle support spread up to $200 \mathrm{~mm}$ from the top fiber. The flexural shear crack started at load $155 \mathrm{kN}$. The shear crack was observed at load $220 \mathrm{kN}$ with a distance of $300 \mathrm{~mm}$ from the end support, whereas the shear crack at the negative moment region started at load $400 \mathrm{kN}$. The flexural shear cracks were observed clearly for beam C3.

C4. Although the cracks concentrated at the maximum moment regions, their width was greater compared to the rest of the beams. At load 96 and $170 \mathrm{kN}$, the cracks extended at the sagging and hogging region respectively. It is also a noticeable increase in the number of cracks at the central support region and the flexural failure was clearly shown without influential shear cracks in the failure mode.

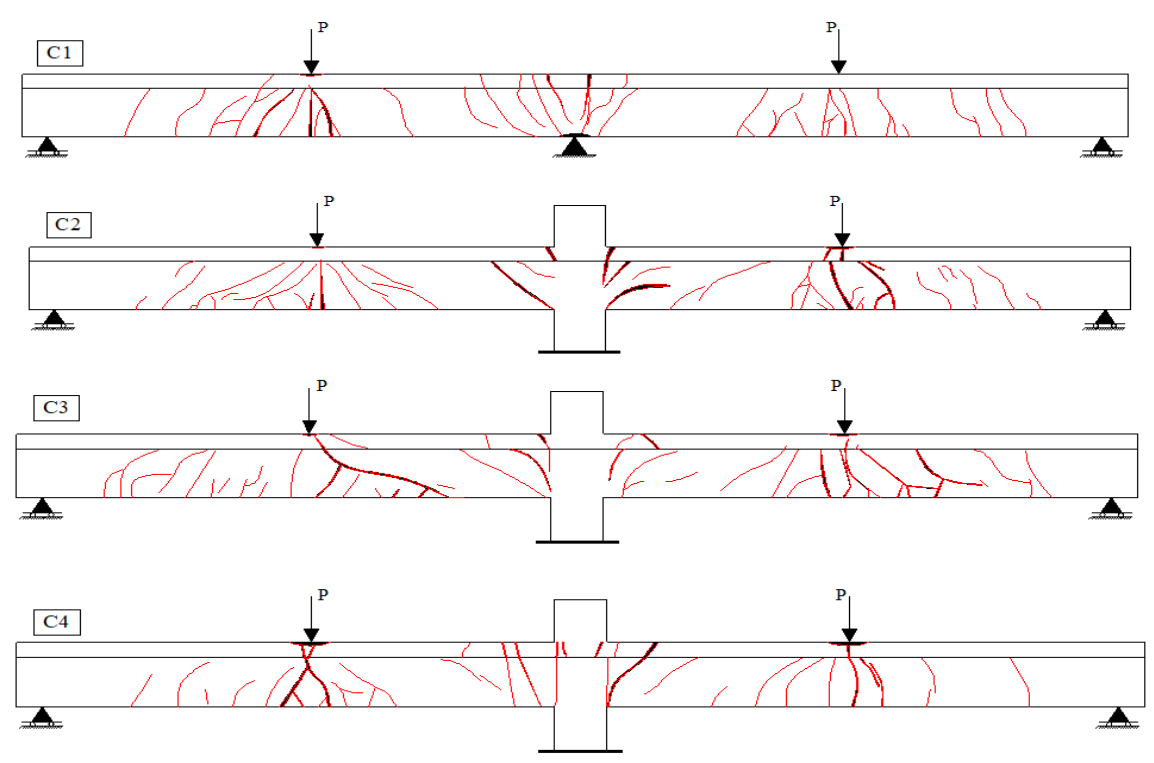

Figure 3 Cracking patterns for beams $\mathrm{C} 1, \mathrm{C} 2, \mathrm{C} 3$ and $\mathrm{C} 4$ 
Hesham M. A. Diab, Tarek Abdelaleem Abdelfattah Khaled and Mohamed M. M. Rashwan

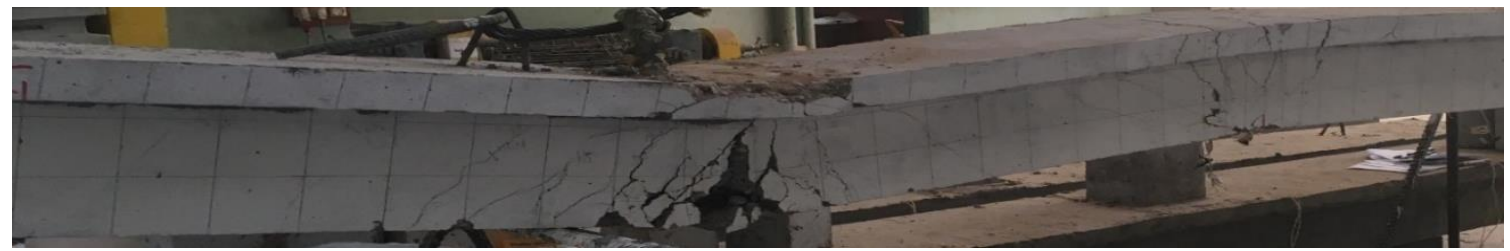

General view

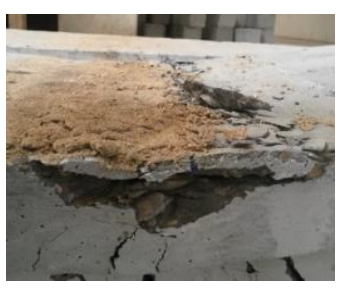

4-a Concrete crushing at mid span region

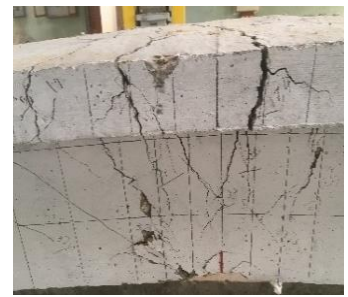

4-b Middle support region

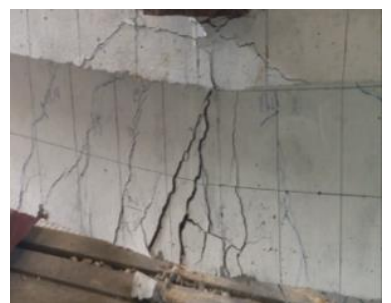

4-c Mid-span region

Figure 4 Failure modes of beam $\mathrm{C} 1$.

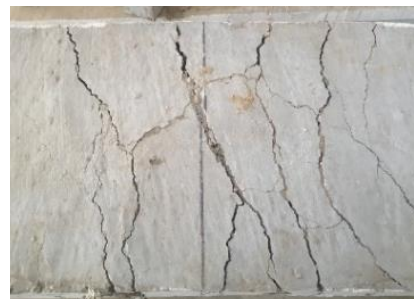

4-d Top view at middle support

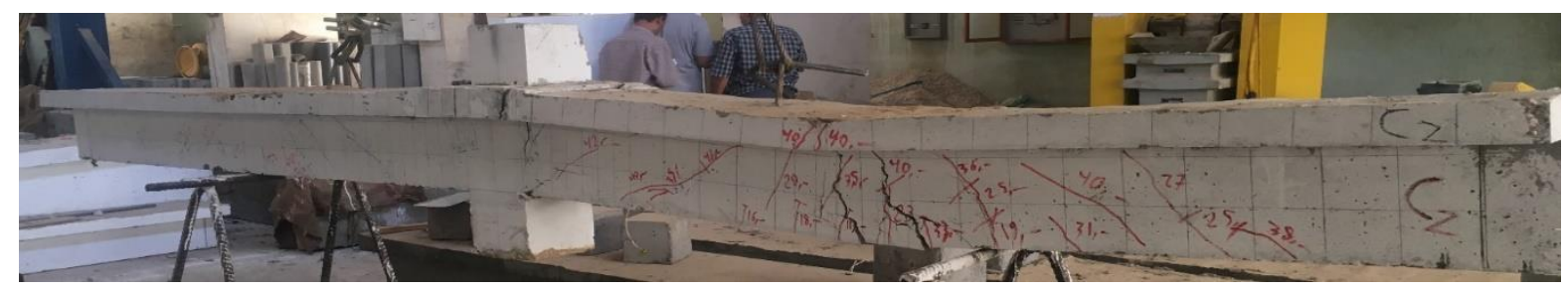

General view

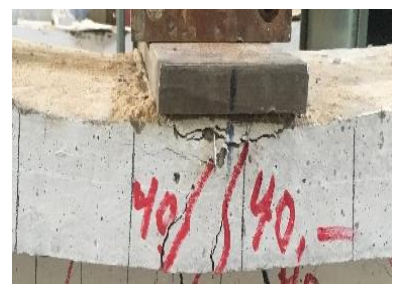

5-a Concrete crushing at mid-span region.

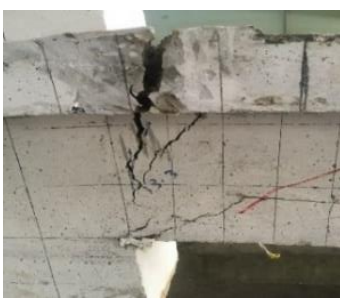

5-b Middle support region.

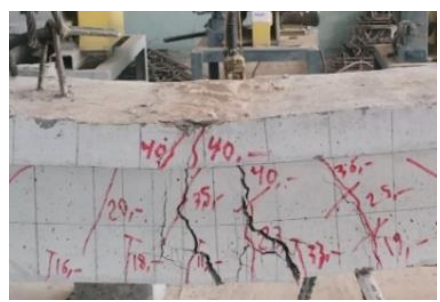

5-c Mid-span region.

Figure 5 Failure modes of beam $\mathrm{C} 2$.

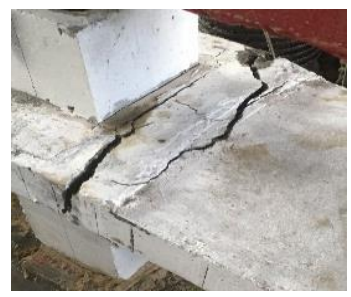

5-d Top view at middle support.

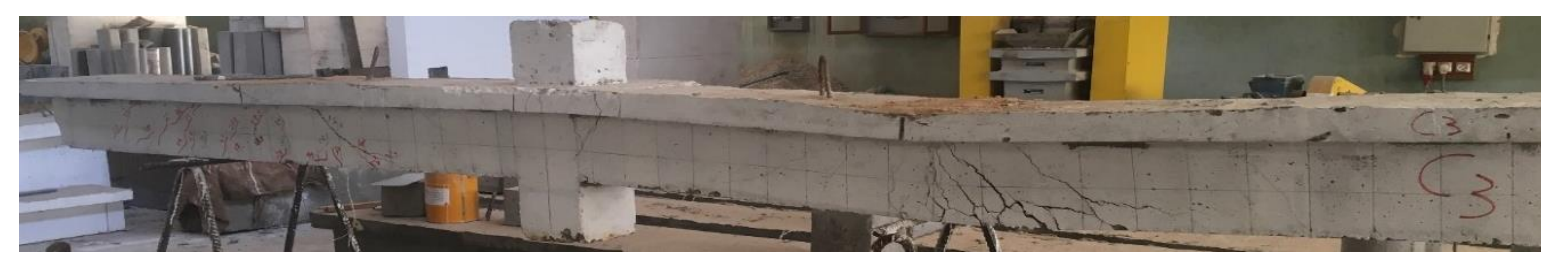

General view

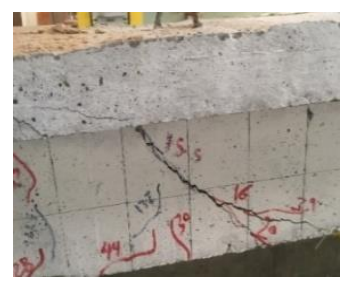

6-a Flexural shear crack.

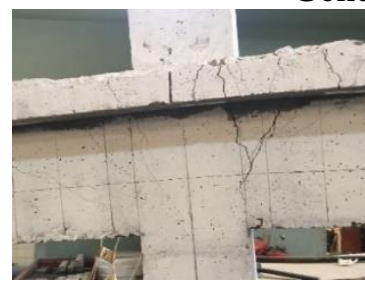

6-b Middle support region

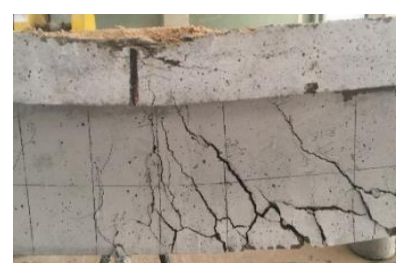

6-c Mid-span region

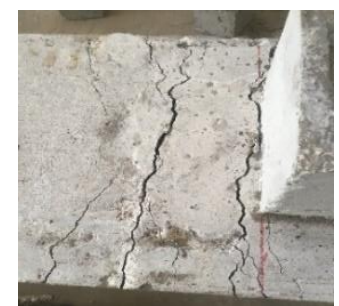

6-d Top view at middle support

Figure 6 Failure modes of beam C3 


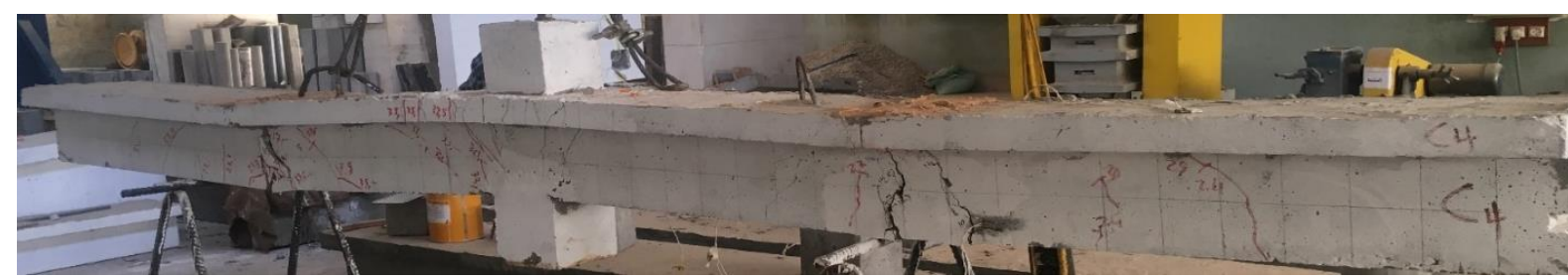

General view

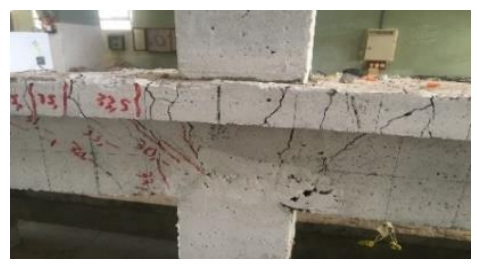

7-a Middle support region

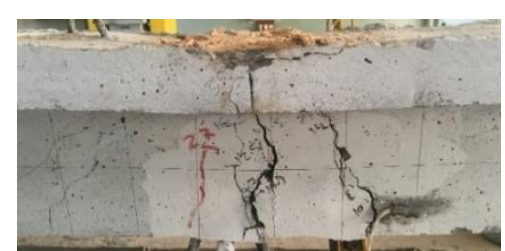

7-b Mid-span region

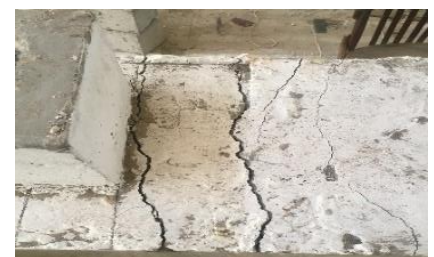

7-c Top view at middle support

Figure 7 Failure modes of beam $\mathrm{C} 4$

\subsection{Load-Deflection Response and Ductility Analysis}

The relationship between the applied load and mid-span deflection for all tested beams is shown in Figure 8. In general, with the beginning of the loading, the beams presented linear load-deflection behaviour with a steep slope at the uncracked stage. After cracking, the flexural stiffness was reduced with the increase of the test machine load and the value of the deflection quickly increased. The reinforcement ratio at the sagging and hogging region affected the stiffness of the beam specimens, also on the load-deflection curve. The same behaviour for the beams $\mathrm{C} 1, \mathrm{C} 2$, and $\mathrm{C} 3$ has been observed because they had the same bottom reinforcement which has a major effect on the flexural stiffness of the beams. Despite the difference in the yielding load of the top reinforcement, they exhibited the same disposition after the ultimate load. This behaviour after the ultimate load was as follows, the load decreased by about $10 \%$ of the ultimate load value, then it increased again by $20-40 \mathrm{kN}$ with a rapid increase in the deflection due to the significant rotation over the middle support, after that, the load decreased until failure of the specimens. The beam $\mathrm{C} 4$ was completely different after cracking load, due to the lower axial stiffness of the mid-span section than the others. The load-deflection curve was less steep from beams C1, C2 and C3 at the post-cracking stage, a third stage that started after yielding of the top reinforcement had an increase in load with lower rate until the failure.

Serviceability is a basic attribute for comparison, so the maximum deflection should be compared to the allowable permitted deflections in codes and design guidelines. The allowable deflection permitted by [24 and 27] ranges from L/480 to L/180 depending on the type and function of the structure. The allowable deflection for tested beams according to [24 and 27] should be within the range of 4.27-11 mm (2,050/480 to 2,050/180) based on the type of structural application. From Fig. 9, the service loads for beams C1, C2, C3 and C4 were from $(188-437.75),(260-467),(263,497.75)$ and $(215-330) \mathrm{kN}$ respectively. It is obvious that the bottom reinforcement affected the service load, so the service loads for beam $\mathrm{C} 2$ were higher than the service loads for beam $\mathrm{C} 4$, although $\mathrm{C} 4$ had top reinforcement area more than beam $\mathrm{C} 2$ by $70 \%$. Moreover, it is worthy to note that the service loads for beams $\mathrm{C} 2$ and $\mathrm{C} 3$ are convergent where the bottom reinforcement was equal. Table 4 shows the values of the deflection for all tested beams at cracking, service, yield, ultimate and failure load. The service load in Table 4 was calculated for beam C3 $(263 \mathrm{kN})$ at the allowable deflection $(4.27$ $\mathrm{mm})$. 
The displacement ductility index is expressed in this study as follows [28].

$$
\begin{aligned}
& \mu_{\Delta u}=\Delta_{u} / \Delta_{y} \\
& \mu_{\Delta f}=\Delta_{f} / \Delta_{y}
\end{aligned}
$$

Where $\Delta_{u}$ and $\Delta_{f}$ is the mid-span deflection at the beam ultimate load and failure load, and $\Delta_{y}$ is the midspan deflection at the yielding load of the tensile steel reinforcement at the central support, $\mu_{u}$ and $\mu_{f}$ is the displacement ductility index at ultimate load (maximum load-carrying capacity) and at failure load. The displacement ductility index $\left(\mu_{\Delta}\right)$ is given in Table 4. Table 4, shows the ductility of the beam specimens with centrally- loaded column is higher than $\mathrm{C} 1$ (continuous beam without column) at ultimate load only, where the deflection at the yield load for the beam C3 was lower than the deflection at the beam $\mathrm{C} 1$ due to the column which helped to increase the stiffness of the middle section. By comparing the beams (C2, C3 and C4), it is obvious that with the decrease of top reinforcement (C2) the ductility of the beams increased. Where the displacement ductility index at ultimate and failure loads was higher than $\mathrm{C} 3$ by about $(61 \%$ and $84 \%)$ respectively, due to the yielding of the top reinforcement at a lower level of loading. But beam (C4) had a displacement ductility index at ultimate load more than $\mathrm{C} 3$ by about $169 \%$, as a result of the yielding of the top and bottom longitudinal reinforcement at a convergent level of loading. It also made it with lower displacement ductility index at failure load.

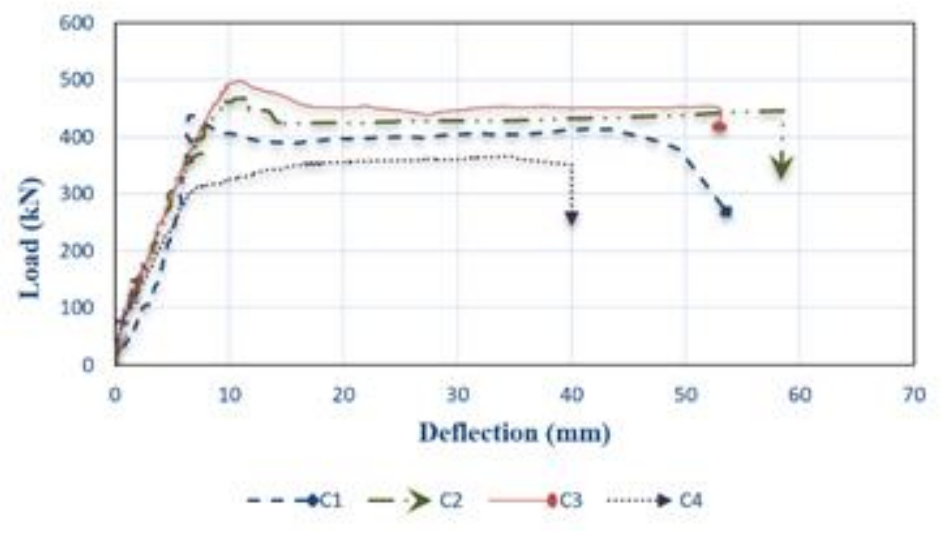

Figure 8 Load-deflection relationship for the tested beams

Table 4 Deflection of the tested beams at different levels of loading.

\begin{tabular}{|c|c|c|c|c|c|}
\hline Beam & $\begin{array}{c}\text { At cracking } \\
\text { load }(\mathbf{m m})\end{array}$ & $\begin{array}{c}\text { At service } \\
\text { load }(\mathbf{m m})\end{array}$ & $\begin{array}{c}\text { At yield load } \\
(\mathbf{m m})\end{array}$ & $\begin{array}{c}\text { At ultimate } \\
\text { load (mm) }\end{array}$ & $\begin{array}{c}\text { At failure load } \\
(\mathbf{m m})\end{array}$ \\
\hline $\mathrm{C} 1$ & 1.85 & 5.45 & 5.76 & 7.02 & 49.51 \\
\hline $\mathrm{C} 2$ & 1.12 & 4.28 & 4.92 & 11.37 & 58.54 \\
\hline $\mathrm{C} 3$ & 0.64 & 4.27 & 7.69 & 10.76 & 52.98 \\
\hline $\mathrm{C} 4$ & 0.84 & 5.5 & 8.58 & 33.88 & 40 \\
\hline
\end{tabular}

*Deflection at service load $(263 \mathrm{kN})$ was calculated for beam C3.

Table 5 Summary of ductility index.

\begin{tabular}{|c|c|c|c|c|c|}
\hline Beam & $\boldsymbol{\Delta}_{\boldsymbol{y}} \mathbf{~ m m}$ & $\boldsymbol{\Delta}_{\boldsymbol{u}} \mathbf{~ m m}$ & $\boldsymbol{\Delta}_{\boldsymbol{f}} \mathbf{m m}$ & $\boldsymbol{\mu}_{\boldsymbol{\Delta} \boldsymbol{u}}$ & $\boldsymbol{\mu}_{\boldsymbol{\Delta} \boldsymbol{f}}$ \\
\hline $\mathrm{C} 1$ & 6.679 & 7.02 & 49.51 & 1.05 & 7.41 \\
\hline $\mathrm{C} 2$ & 4.619 & 11.37 & 58.54 & 2.46 & 12.67 \\
\hline $\mathrm{C} 3$ & 7.69 & 11.76 & 52.98 & 1.53 & 6.89 \\
\hline $\mathrm{C} 4$ & 8.58 & 35.32 & 40 & 4.12 & 4.66 \\
\hline
\end{tabular}




\subsection{Moment Redistribution}

The moment redistribution ratio $(\beta)$ given in Table 6 was calculated for the sagging and the hogging bending moment at mid-span and the central support, observed from the initiation of the load process until structural collapse. The ratio was calculated by:

$$
\beta \%=\frac{M_{e}-M_{e x}}{M_{e}} * 100
$$

Where $M_{e}$ is the value of the moment at central support and mid-span is based on the elastic analysis and $M_{e x}$ is the experimental value of bending moment at any stage of loading. Figures (9 and 10) and Table 6 show the load-moment redistribution relationship at the hogging and sagging regions. The moment redistribution ratio $(\beta \%)$ for all specimens was negative value before the beam cracking at the hogging region, which means that the experimental moment at the uncracked sections of the hogging region was more than the elastic moment due to the properties of the cross-sections. So the internal forces were redistributed from the sagging to the hogging region, and this value continued to decrease until it reached zero percentage at cracking load. after the cracking loads, the moment was redistributed from the negative moment section to the positive moment sections due to the difference in the flexural stiffness at the critical sections. The moment redistribution increased slowly until the yield loads, then moment redistribution ratio increases rapidly up to failure loads. The moment redistribution ratio of the beam $(\mathrm{C} 2)$ at the service load was 3.0 times greater than the moment redistribution of the beam (C3).

This difference reduced with the transition between the load levels toward the failure point. The beam $(\mathrm{C} 4)$ had the least moment redistribution ratio where the axial stiffness of the main reinforcement at the critical sections was almost equal. The value of the moment redistribution ratio was reduced to zero percentage after the yield loads, because of yielding of the bottom reinforcement directly after the yielding of the bottom reinforcement. In general, the redistribution of the internal forces increased until the crack formation occurred at the span sections, resulting in a flexural stiffness reduction.

Table 6 Central support reaction, moments at service, yield, ultimate and failure load and moment redistribution of tested beams.

\begin{tabular}{|c|c|c|c|c|}
\hline \multicolumn{2}{|c|}{ Beam specimen } & $\boldsymbol{P}_{\mathbf{k N}}$ & \multicolumn{2}{c|}{$\% \boldsymbol{\beta}$} \\
\hline \multirow{2}{*}{} & & $\begin{array}{c}\text { Central } \\
\text { support }\end{array}$ & Mid span \\
\hline \multirow{2}{*}{$\begin{array}{c}\text { At service load } \\
(\Delta=\mathrm{L} / 480)\end{array}$} & $\mathrm{C} 1$ & 188 & 13.6 & $\mathbf{- 8 . 1 6}$ \\
\cline { 2 - 5 } & $\mathrm{C} 2$ & 260 & 22.65 & $\mathbf{- 1 3 . 5 8}$ \\
\cline { 2 - 5 } & $\mathrm{C} 3$ & 263 & 5.54 & $\mathbf{- 3 . 3 2}$ \\
\cline { 2 - 5 } & $\mathrm{C} 4$ & 215 & 7.4 & $\mathbf{- 4 . 4 6}$ \\
\hline \multirow{3}{*}{$\begin{array}{c}\text { yield load at } \\
\text { the hogging } \\
\text { region }\end{array}$} & $\mathrm{C} 1$ & 393.75 & 27.5 & $\mathbf{- 1 8 . 1}$ \\
\cline { 2 - 5 } & $\mathrm{C} 2$ & 295 & 22.5 & $\mathbf{- 1 2 . 3 1}$ \\
\cline { 2 - 5 } & $\mathrm{C} 3$ & 419.5 & 12.59 & $\mathbf{- 7 . 7 9}$ \\
\cline { 2 - 5 } & $\mathrm{C} 4$ & 306.25 & 9.22 & $\mathbf{- 5 . 5 4}$ \\
\hline \multirow{3}{*}{$\begin{array}{c}\text { At ultimate } \\
\text { load }\end{array}$} & $\mathrm{C} 1$ & 437.5 & 28.0 & $\mathbf{- 2 2 . 0}$ \\
\cline { 2 - 5 } & $\mathrm{C} 2$ & 467.5 & 25.61 & $\mathbf{- 1 5 . 4 0}$ \\
\cline { 2 - 5 } & $\mathrm{C} 3$ & 497.75 & 19.56 & $\mathbf{- 1 2 . 1 2}$ \\
\cline { 2 - 5 } & $\mathrm{C} 4$ & 365.5 & -5.0 & $\mathbf{+ 3 . 0}$ \\
\hline
\end{tabular}




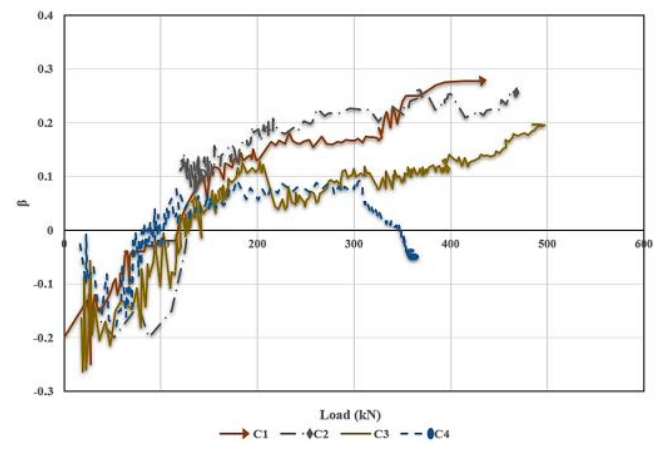

Figure 9. Load-moment redistribution ratio at Fi the hogging region for all tested beams.

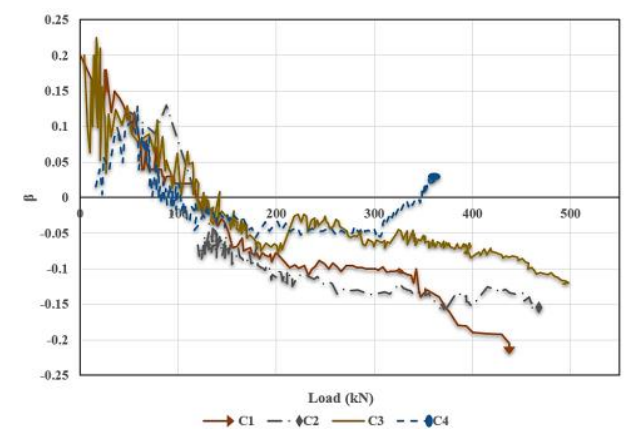

Figure 10. Load-moment redistribution ratio at the sagging region for all tested beams.

\section{ANALYTICAL MODEL}

\subsection{Concrete in Compression}

The recorded maximum compressive stress in a real beam differs from that obtained in a cylinder or a cube test. Several studies have indicated that the ratio of the maximum compression stress in beams or columns to the cylinder compressive strength $f_{c^{\prime}}$ can be taken equal 0.85 for most practical purpose [29 and 30]. This accounts for the size effect and the fact that the beam is subject to a sustained load while the cylinder is tested during a short period. Furthermore, since the cylinder strength $f_{c}$ is about 0.80 of cube strength $f_{c u}$, the maximum value of the stress-strain curve for beams or columns $0.67 f_{c u}$. The Egyptian code (ECCS 203) [27] presents an idealization for the stress strain curve in compression. The first part of the curve is a parabolic curve up to a strain of 0.002 and the second part is a straight horizontal line up to a strain of 0.003 , as shown in Figure.11. Referring to Figure.11, the equation of the concrete stress $f_{c}$ in terms of the concrete strain $\left(\varepsilon_{c}\right)$ can be expressed as:

$$
f_{c}=\left\{\begin{array}{cl}
f_{c^{\prime}}\left(\left(\frac{2 \varepsilon_{c}}{0.002}\right)-\left(\frac{\varepsilon_{c}}{0.002}\right)^{2}\right) & \text { for } \varepsilon_{c}<0.002 \\
f_{c^{\prime}} & \text { for } 0.002 \leq \varepsilon_{c} \leq 0.003
\end{array}\right.
$$

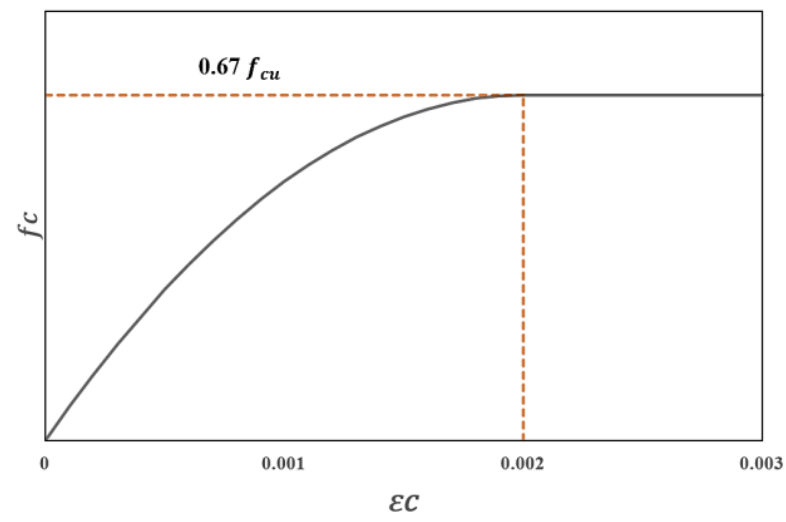

Figure 11 ECCS 203 idealizes stress-strain curve for concrete.

\subsection{Calculation of Resisting Moment}

The internal resisting moment $(\mathrm{M})$ of the section can be obtained by taking the sum of the moments about the middle height of the section or about the neutral axis. The neutral axis depth, $c$, is obtained from the equilibrium of internal forces for different state. Attributable to use the experimental stress-strain curve for steel these states include (a) before cracking of 
concrete; (b) after cracking of concrete and before yielding of steel; (c) After yielding; (d) steel strain hardening state. The neutral axis depth and the internal resisting moment are obtained as follow:

$$
\begin{aligned}
& A c^{2}+B c+C=0 \\
& c=\frac{-B+\sqrt{B^{2}-4 A C}}{2 A}
\end{aligned}
$$

(a) Before cracking of concrete $\left[f_{c} \leq f_{c t}\right]$ :

$f_{c t}$ is the value of the concrete tensile strength $\left(f_{c t}=0.6 \sqrt{f_{c u}} M P a\right)$, The neutral axis depth can be determined, before the concrete has cracked, by:

$$
\begin{gathered}
A=\beta_{1} f_{c} b-\varepsilon_{c} E_{c} \frac{b}{2} \\
B=\varepsilon_{c} E_{s}\left(A_{s}+A_{s^{\prime}}\right)+\varepsilon_{c} E_{c} b h \\
C=-\varepsilon_{c} E_{s}\left(A_{s} d+A_{s^{\prime}} d^{\prime}\right)+\varepsilon_{c} E_{c} \frac{b}{2} h^{2} \\
M_{u}=f_{c} b c\left(\frac{t}{2}-\beta_{1} c\right)+A_{s^{\prime}} E_{s} \varepsilon_{s^{\prime}}\left(\frac{t}{2}-d^{\prime}\right)+A_{s} E_{s} \varepsilon_{s}\left(d-\frac{t}{2}\right) \\
+\frac{1}{3} \varepsilon_{c} E_{c} b(t-c)^{2}
\end{gathered}
$$

Where $\beta_{1}$ is the ratio between the depth of the equivalent rectangular concrete stress block and that of the neutral axis, $b, t$, and $d$ are the width, total depth, effective depth of the beam section $(\mathrm{mm}), d^{\prime}$ is the distance from extreme compressive fiber to centroid of the compressive steel $(\mathrm{mm}), E_{c}$ is the concrete modulus of elasticity $\left(E_{c}=4400 \sqrt{f_{c u}} M P a\right)$, $E_{S}$ is the steel modulus of elasticity, and $A_{s}$ and $A_{s}$ are the total cross-section area of tensile and compressive steel $\left(\mathrm{mm}^{2}\right)$ respectively,

(b) After cracking of concrete and before yielding of steel $\left[f_{c}>f_{c t}, f_{s}<f_{y}\right]$ :

The concrete in tension cracks and therefore all concrete below the neutral axis is neglected.

$$
\begin{aligned}
& \beta_{1} f_{c} c b+A_{s^{\prime}} f_{s^{\prime}}=A_{s} f_{s} \\
& A=\beta_{1} f_{c} b \\
& \quad B=\varepsilon_{c} E_{s}\left(A_{s}+A_{s^{\prime}}\right) \\
& \quad C=-\varepsilon_{c} E_{s}\left(A_{s} d+A_{s^{\prime}} d^{\prime}\right) \\
& M_{u}=A_{s^{\prime}} E_{s} \varepsilon_{s^{\prime}}\left(\frac{\beta_{1} c}{2}-d^{\prime}\right)+A_{s} E_{s} \varepsilon_{s}\left(d-\frac{\beta_{1} c}{2}\right)
\end{aligned}
$$

(c) After yielding and before strain hardening of steel $\left[f_{s}=f_{y}\right]$ :

$$
\begin{aligned}
& \beta_{1} f_{c} c b+A_{s^{\prime}} f_{s^{\prime}}=A_{s} f_{y} \\
& A=\beta_{1} f_{c} b \\
& B=\varepsilon_{c} E_{s} A_{s^{\prime}}-A s f_{y} \\
& C=-\varepsilon_{c} E_{s} A_{s^{\prime}} d^{\prime} \\
& M_{u}=A_{s^{\prime}} E_{s} \varepsilon_{s^{\prime}}\left(\frac{\beta_{1} c}{2}-d^{\prime}\right)+A_{s} f_{y}\left(d-\frac{\beta_{1} c}{2}\right)
\end{aligned}
$$


(d) After yielding and before strain hardening of steel $\left[f_{s}>f_{y}\right]$ :

$$
\begin{aligned}
& \beta_{1} c b+A_{s^{\prime}} f_{s^{\prime}}=A_{s} f_{s} \\
& A=\beta_{1} f_{c} b \\
& B=\varepsilon_{c} E_{s} A_{s^{\prime}}-A s f_{s} \\
& C=-\varepsilon_{c} E_{s} A_{s^{\prime}} d^{\prime} \\
& M_{u}=A_{s^{\prime}} E_{s} \varepsilon_{s^{\prime}}\left(\frac{\beta_{1} c}{2}-d^{\prime}\right)+A_{s} f_{s}\left(d-\frac{\beta_{1} c}{2}\right)
\end{aligned}
$$

The predicted ultimate load P (total load at the beam) for a fully ductile beam, the flexural load capacity is based on a collapse mechanism with plastic hinges at mid-span and central support sections. Thus, the flexural load capacity on each span would be calculated from [31]:

$$
P=\frac{4}{2.05}\left(2 M_{s}+M_{h}\right)
$$

Where the $M_{s}$ and $M_{h}$ are the predicted moments at the sagging and hogging regions respectively.

Table 7 present the experimental and predicted moment and load capacities for continuous tested beams. The experimental failure moments at mid-span and middle support regions are

\begin{tabular}{|c|c|c|c|c|c|c|c|}
\hline \multirow{2}{*}{ Specimen } & \multicolumn{2}{|c|}{ Central Support } & \multicolumn{2}{|c|}{ Mid-span } & \multirow{2}{*}{$\begin{array}{c}\boldsymbol{P}_{\text {exp. }} \\
\mathbf{k N}\end{array}$} & \multirow{2}{*}{$\begin{array}{c}P_{\text {pre }} \\
\mathbf{k N}\end{array}$} & \multirow{2}{*}{$\begin{array}{l}\text { Exp } \\
\text { /Pre }\end{array}$} \\
\hline & $\begin{array}{c}M_{\text {exp. }} \\
(\mathbf{k N ~ m})\end{array}$ & $M_{(\mathrm{kN} \mathrm{m})}$ & $\begin{array}{c}M_{\exp } \\
(\mathbf{k N ~ m})\end{array}$ & $M_{(\mathbf{k N ~ m})}$ & & & \\
\hline $\mathrm{C} 1$ & -64.55 & -51.95 & 79.83 & 102.50 & 437.5 & 501.4 & 0.87 \\
\hline $\mathrm{C} 2$ & -67.40 & -34.0 & 86.1 & 102.0 & 467.5 & 466.0 & 1.0 \\
\hline $\mathrm{C} 3$ & -83.9 & -51.95 & 85.60 & 102.50 & 498 & 501.4 & 0.99 \\
\hline $\mathrm{C} 4$ & -70 & -53 & 57.8 & 58.0 & 362.25 & 330 & 1.1 \\
\hline
\end{tabular}
calculated from the measured end support reaction and mid-span point load at failure of each beam. It can be seen from Tables 7 that the previous equations practically predicted the ultimate total loads for the tested continuous steel beams especially for beams with central loaded columns.

Table 7 Comparison between experimental and predicted results.

\subsection{Mid-Span Deflection Predictions}

The immediate deflection $\Delta$ of continuous reinforced concrete beams loaded with a mid-span point load could be calculated by Eqs. (28) [31], as given below:

$$
\Delta=\frac{7}{768} \frac{p l^{3}}{E_{c} I_{e}}
$$

Where $p$ is the mid-span applied load at which the deflection is computed, $l$ is the span length, $E_{c}$ is the modulus of elasticity of concrete and $I_{e}$ is the effective moment of inertia of 
the beam section. An expression for the effective moment of inertia $I_{e}$ to be used for predicting the deflection is given by ACI 440.1R-15 [32] as follows.

$$
I_{e}=\frac{I_{c r}}{1-\gamma\left(\frac{M_{c r}}{M_{a}}\right)^{2}\left[1-\frac{I_{c r}}{I_{g}}\right]} \leq I_{g}
$$

Where $M_{c r}$ is the cracking moment, $M_{a}$ is the applied moment, $\gamma$ is a factor which accounts for the length of the uncracked regions of the member and for the change in stiffness in the cracked regions $=1.72-0.72 \frac{M_{c r}}{M_{a}} . I_{g}$ is the gross moment of inertia, $I_{c r}$ is the moment of inertia of transformed cracked section according to equations (30 and 31).

$$
\begin{gathered}
I_{c r}=\frac{1}{3} b c^{3}+n_{s} A_{s} d^{2}\left(1-\frac{c}{d}\right)^{2} \\
n_{s}=\frac{E_{s}}{E_{C}}
\end{gathered}
$$

A better estimate of the effective moment of inertia, $I_{e}$, is obtained by using the weighted average properties as follows [16]:

(a) Beam span with two continuous ends:

$$
I_{e}=0.7 I_{m}+0.15\left(I_{e 1}+I_{e 2}\right) .
$$

(b) Beam span with one end continuous:

$$
I_{e}=0.85 I_{m}+0.15 I_{e 1},
$$

Where $I_{m}, I_{e 1}$ and $I_{e 2}$ represent the effective moment of inertia of the beam at mid-span and continuous ends, respectively.

The comparisons between the experimental and theoretical load-deflection diagrams for the tested beams are shown in Figures. (12, 13, 14, and 15).

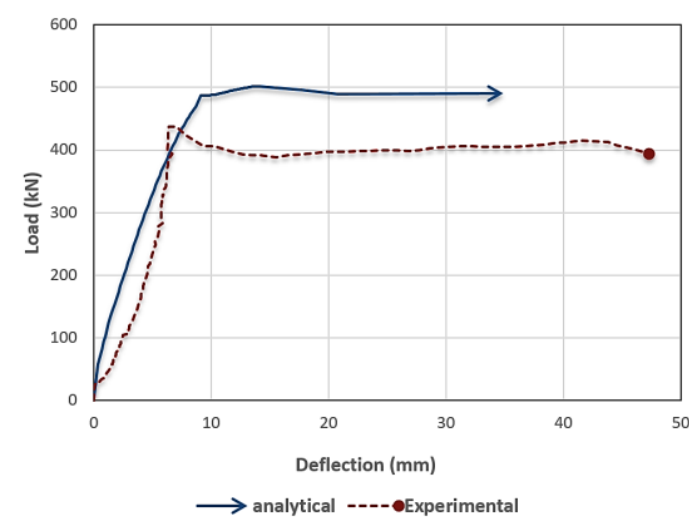

Figure 12 Analytical versus experimental deflection for beam $\mathrm{C} 1$.

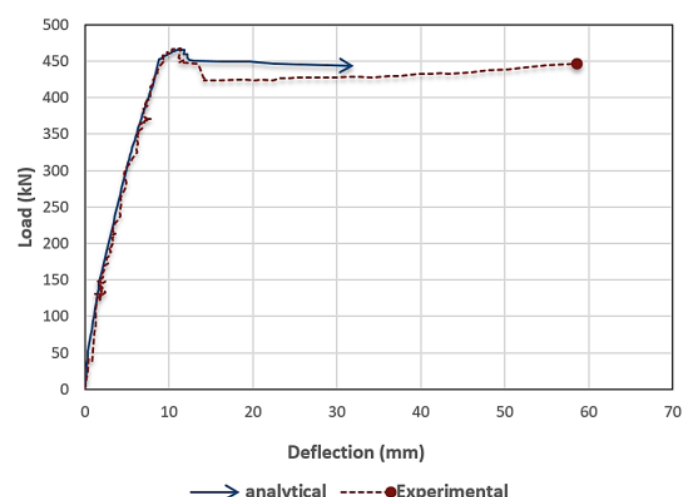

Figure 13 Analytical versus experimental deflection for beam $\mathrm{C} 2$. 
Hesham M. A. Diab, Tarek Abdelaleem Abdelfattah Khaled and Mohamed M. M. Rashwan

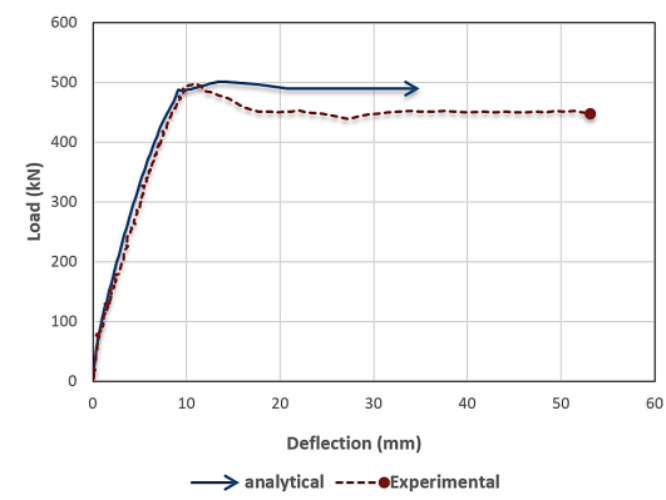

Figure 14 Analytical versus experimental deflection for beam $\mathrm{C} 3$.

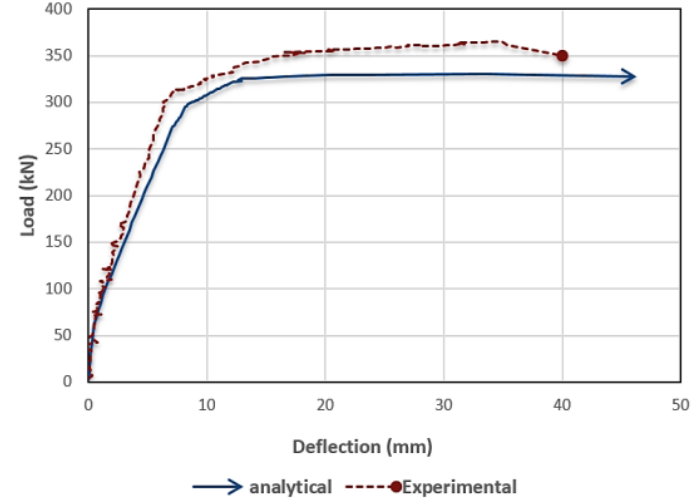

Figure 15 Analytical versus experimental deflection for beam $\mathrm{C} 4$.

\section{CONCLUSIONS RECOMMENDATIONS}

Experimental work was carried out on four large-scale RC continuous T-beams, to study the effect of reduction of upper or bottom longitudinal reinforcement and the central loaded column on the general behaviour of the tested beams and their ability to redistribute bending moment between hogging and sagging regions under the influence of vertical loads. Based on the test results and the comparisons between the tested beams which was presented in advance in this research we can draw the following conclusions:

- The distribution of the cracks along the beam span relies on the ration between the hogging and the sagging reinforcement, where the cracks concentrate at the maximum moment regions at the approximation in the reinforcement areas. In contrast, there is an increase in the number of cracks and their spread along the beam span with an increase in the area of the bottom steel reinforcing.

- The ultimate load capacity, service loads and flexural rigidity are affected by the sagging main reinforcement significantly.

- The top reinforcement area had influence on the moment redistribution in RC continuous concrete beams even before reaching the yield load, and the hogging moment redistribution over the middle support is always larger than that at the midspan because the stiffness of the middle section was lower than the mid-span region, where the flange was fully cracked before the yielding loads.

- The formation of the plastic hinge at the mid-span region depends mainly on the ratio between upper and lower reinforcement, where increasing the lower reinforcement area compared to the upper reinforcement leads to formation the plastic hinge after the ultimate load and this helps to improve the ductility of the beam and give an amble warning before failure.

- The central loaded column helps to increase the moment capacity at the central support and reduces the redistribution of the internal forces between the negative and positive moment regions.

- Based on the findings of this study, future research may study the effect of the sagging /hogging longitudinal steel reinforcement ratio and the hogging /sagging longitudinal steel reinforcement ratio with the numerical analysis on the flexural behaviour, serviceability and moment redistribution ratios.

- Derive equations for calculating the yield load at each region and ultimate load with different reinforcement ratios. 
- Study the size effect with different reinforcement ratios on the flexural behaviour and design equations for the RC continuous T-beams with the numerical analysis.

- Study the strengthening of the RC continuous beams by NSM bars at sagging or hogging region.

\section{REFERENCES}

[1] Saadatmanesh H, Ehsani MR. RC beams strengthened with GFRP plates. I: Experimental study. Journal of Structural Engineering; 117(11): 3417-33. 1991.

[2] Jaeger, L. G., Tadros, G., and Mufti, A. A. (1995). Balanced section, ductility and deformability in concrete with FRP reinforcement. Res. Rep., Joint U.S. Can Meeting at West Virginia Univ., Morgantown, W. Va.

[3] Grace NF, Soliman AK, Abdel-Sayed G, Saleh KR. Behavior and ductility of simple and continuous FRP reinforced beams. Journal of Composites for Construction, ASCE; 2(4):18694. 1998.

[4] De Lorenzis L, Teng JG. Near-surface mounted FRP reinforcement: an emerging technique for strengthening structures. Composites: Part B; 38:119-43. 2007.

[5] Sharaky IA, Torres L, Baena M, Vilanova I. Effect of different material and construction details on the bond behaviour of NSM FRP bars in concrete. Construction and Building Materials; 38:890-902. 2013.

[6] Obaydullah M., Jumaat M. Z., Alengaram U. J., Darain Kh. M. ud, Md. Nazmul Huda, Hosen Md. Akter. Prestressing of NSM steel strands to enhance the structural performance of prestressed concrete beams. Construction and Building Materials 129, 289-301. 2016.

[7] Diab Hesham M. , Farghal Omer A. Bond strength and effective bond length of FRP sheets/plates bonded to concrete considering the type of adhesive layer. Composites Part B: Engineering Volume 58, March 2014, Pages 618-624.

[8] Niklas Bagge, Alan O'Connor, Lennart Elfgren and Claus Pedersen. Moment redistribution in $\mathrm{RC}$ beams - A study of the influence of longitudinal and transverse reinforcement ratios and concrete strength. Engineering Structures 80 (2014) 11-23.

[9] Carmo NFC, Lopes SMR. Available plastic rotation in continuous high-strength concrete beams. Journal of Civil Engineering. 2008; 35(10):1152-62.

[10] Bigaj AJ. Structural dependence of rotation capacity of plastic hinge in RC beams and slabs. PhD Thesis. Delft: Delft University; (1999). 230 pages.

[11] Shakir A. Moment redistribution in reinforced concrete structures. PhD Thesis. Edmonton: University of Alberta; (2005). 566 pages.

[12] Ashour A.F., El-Refaie S.A., Garrity S.W. Flexural strengthening of RC continuous beams using CFRP laminates. Cement \& Concrete Composites 26 (2004) 765-775.

[13] Liu I. S. T., Oehlers D. J., and Seracino R. Tests on the ductility of reinforced concrete beams retrofitted with FRP and steel near-surface mounted plates. Journal of Composites for Construction @ ASCE. 2006.10:106-114.

[14] M.A. Aiello, L. Valente, A. Rizzo, Moment redistribution in continuous reinforced concrete beams strengthened with carbon-fiber-reinforced polymer laminates, Mechanics of Composite Materials 43(5) (2007) 453-466.

[15] H. Akbarzadeh and A.A. Maghsoudi. Experimental and analytical investigation of reinforced high strength concrete continuous beams strengthened with fiber reinforced polymer. Materials and Design 31 (2010) 1130-1147. 
[16] A.A. Maghsoudi, H. Akbarzadeh Bengar. Acceptable lower bound of the ductility index and serviceability state of RC continuous beams strengthened with CFRP sheets. Scientia Iranica, Transactions A: Civil Engineering 18 (2011) 36-44.

[17] Farhang Farahbod, Davood Mostofinejad. Experimental study of moment redistribution in RC frames strengthened with CFRP sheets, Composite Structures 93 (2011) 1168-1177.

[18] Marco Andrea Pisani. Numerical Analysis of Continuous Beams Prestressed with External Tendons. J. Bridge Eng. 2009.14:93-101.

[19] Ahmed Ghallab. Calculating ultimate tendon stress in externally prestressed continuous concrete beams using simplified formulas. Engineering Structures 46 (2013) 417-430.

[20] Tiejiong Lou, Sergio M. R. Lopes and Adelino V. Lopes. Flexural Response of Continuous Concrete Beams Prestressed with External Tendons. Journal of Bridge Engineering ( ) ASCE. 2013.18:525-537.

[21] Ahmed Ghallab. Ductility of Externally Prestressed Continuous Concrete Beams. KSCE Journal of Civil Engineering (2014) 18(2):595-606.

[22] Tiejiong Lou, Sergio M.R. Lopes and Adelino V. Lopes Factors affecting moment redistribution at ultimate in continuous beams prestressed with external CFRP tendons. Composites: Part B 66 (2014) 136-146.

[23] J.S. Du, Francis T.K. Au, Enoch K.H. Chan and L. Liu. Deflection of unbonded partially prestressed concrete continuous beams. Engineering Structures 118 (2016) 89-96.

[24] ACI 318M-14, Building Code Requirements for Structural Concrete. An ACI Standard and Commentary, March 2015.

[25] European Committee for Standardization. Eurocode 2: design of concrete structures - Part 11: general rules and rules for buildings. DS/EN 1992-1-1 + AC:2008. Brussels: European Committee for Standardization; (2009).

[26] Canadian Standards Association. Design of concrete structures. A23.3. Mississauga: Canadian Standards Association; (2004).

[27] Egyptian code of practice for design and construction of concrete structures ECCS 203-2017.

[28] R.A. Hawileh, H.A. Rasheed, J.A. Abdalla, A.K. Al-Tamimi, Behavior of reinforced concrete beams strengthened with externally bonded hybrid fiber reinforced polymer systems, Mater. Des. 53 (2014) 972-982.

[29] William Peter Younger Smith, Hans Beushausen. Relating concrete cube, core and cylinder compressive strengths that are cast, cured, prepared and tested in laboratory conditions. Dissertation for the degree of masters of science in engineering, University of Cape Town, Private Bag Rondebosch, 7700 South Africa 7700.

[30] Ritu Kumari. Review Paper Based On the Relation between the Strength of Concrete Cubes and Cylinders. Journal of Engineering Research and Applications. ISSN: 2248-9622, Vol. 5, Issue 8, (Part - 2), (2015) 52-54

[31] Araba. M. A., Ashour F. A. Flexural performance of hybrid GFRP-Steel reinforced concrete continuous beams, Composites Part B 154 (2018) 321-336.

[32] American Concrete Institute (ACI). 'Guide for the Design and Construction of Concrete Reinforced with FRP Bars.' ACI 440.1R-15, Farmington Hills, Mich. (2015). 